\title{
Magdalena Chmielińska*
}

\section{THE ACCEPTANCE CONTROL COSTS FOR VARIABLE SAMPLING IN CASE OF CHARACTERISTIC DISTRIBUTION INCOMPATIBLE WITH ASSUMPTIONS}

\begin{abstract}
The acceptance sampling is the conclusive procedure based on a sample randomly selected from a larger batch of quality in the controlled batch. The inspection can be run in case of a variable assessment and an attribute assessment. Variable sampling assumes that the parameter of quality characteristic follows the normal distribution. The paper presents the procedure of determining the acceptance constant $\mathrm{k}$ of acceptance sampling by set sample size and producer's risk, in the case of distribution of a controlled characteristics significantly different from the normal distribution. In the article the proposed method is compared with the classical method in terms of the generated costs. It is assumed that in the case of distributions significantly different from normal distribution, the proposed method proves to be cheaper in the application.
\end{abstract}

Key words: statistical quality control, acceptance sampling by variable, acceptance sampling costs.

\section{INTRODUCTION}

Acceptance sampling is an inspection and classification of a sample of units selected at random from a larger batch and the ultimate decision about disposition of the lot. Variable and attribute methods are distinguished. Variable sampling assumes that the parameter of quality characteristic follows the normal distribution. Of course it is possible to use variables sampling plans when the parameter of interest does not have a normal distribution. The procedure of determining the acceptance constant $k$ of acceptance sampling by set sample size and the producer's risk, in those case, is proposed in the article.

Application of the classical variable acceptance sampling in case of not normal distribution of the quality characteristic can lead to incorrect decision, which can be a source of additional, unnecessary expense. It is supposed, therefore, that if the distribution of the quality characteristic is significantly different from normal distribution, the costs associated with their use are higher than the costs of carrying out the acceptance inspection in accordance with the proposed alternative approach.

\footnotetext{
* M.Sc., Department of Statistics, Katowice University of Economics.
} 
The aim of the article is to propose a procedure of determining the acceptance constant $k$ of acceptance sampling by set sample size and the producer's risk in case of not normal distribution of the quality characteristic. The hypothesis verified in this article says, that the application of the proposed method was, in this case, cheaper in comparison with the classical method. We will verify the hypothesis on the basis of the results of computer simulations.

\section{DESCRIPTION OF ACCEPTANCE SAMPLING}

Acceptance sampling plan is the procedure of deciding the quality of batch on the basis of the sample, which is randomly selected from this batch. It helps determine which lots of items are acceptable and which are unacceptable and should be reworked or scrapped. Acceptance sampling as an "off - line" method is applied at a time when production of the batch is completed, because their purpose is to protect the recipient from taking products that do not meet their quality requirements. Sampling plans can be classified by attributes and variables.

The variable acceptance sampling can be used as alternative to attribute plans when measurement data are available. These plans are based on measuring average and variability of examined feature, and they assume that the parameter of interest follows the normal distribution which mean $\mu$ and standard deviation $\sigma$ (Wetherill, Chiu, 1975). The variable acceptance sampling may be built in case of known and unknown $\sigma$.

Since the quality characteristic is a variable, there will exist either a lower specification limit $(L)$, an upper specification limit $(U)$, or both, that define the acceptable values of this parameter (D. C. Montgomery, 2009). The classical condition for one - sided, lower specification limit $L$, in case of known $\sigma$, is presented by the formula:

$$
\frac{\bar{x}-L}{\sigma} \geq k
$$

The acceptance constant $\mathrm{k}$ is determined from the formula:

$$
k=\frac{z_{\alpha}}{\sqrt{n}}-z_{p_{2}}
$$

where:

$n$ - the sample size,

$p_{2}$ - the acceptable level of defectiveness,

$\alpha$-the probability of rejecting a batch of defective equal $p_{2}$. 


\section{THE ACCEPTANCE SAMPLING COSTS}

The concept of quality control costs means all enterprise's costs connected with conducting quality control. Among costs of statistical quality control, there were distinguished costs of prevention, costs of examination and estimation, loss of internal lack and loss of external lack (Iwasiewicz, 1999). Total quality control cost is a sum of all distinguished groups of costs.

The total acceptance control cost consists of costs of examination and estimation, loss because of internal and external lack. The costs of examination and estimation depend on single costs of control $\left(k_{k}\right)$ and on amount of controlled pieces. Loss of internal lack, depends on cost of exchange (or repair) of defective element $\left(k_{b w}\right)$ and on amount of damaged elements detected in sample, in case of acceptance batch, or on amount of damaged elements detected in batch, in case of its rejection (Kończak, 2007). Loss of external lack is found only in the situation, when the batch is accepted. This cost embraces the guarantee repairs and loss as a result of forfeiture of customers and company reputation.

\section{A PROCEDURE OF DETERMININIG THE ACCEPTANCE CONSTANT $k$ OF ACCEPTANCE SAMPLING BY SET SAMPLE SIZE AND PRODUCER'S RISK}

The procedure of determining the variable acceptance by the set of sample size and the producer's risk, in the case of distribution of a controlled characteristics significantly different from the normal distribution is as follows:

1. Simulation designation of distribution of the average of $n-$ element samples based on historical results of measurements of the characteristics $X$,

2. Determining the empirical distribution $X^{*}=\frac{\bar{X}-m}{s}$, where $m-$ the expected value, $s$ - standard deviation of a random variable $X$ estimated based on historical data,

3. Determining the empirical distribution $X^{* *}=\frac{X-L}{s}$, where $L-$ lower specification limit for feature $X$,

4. Estimation of unknown distributions $X^{*}, X^{* *}$ (i.e. using Pearson's curves),

5. Reading the quantile of the order $p_{2}$ of the distribution $X^{* *}$, obtaining value $x_{p_{2}}^{* *}$, 
6. Reading the quantile of the order $\alpha$ of the distribution $X^{*}\left(x_{\alpha}^{* *}\right)$, and reading the cumulative distribution function $X^{*}$ at the point of $x_{p_{2}}^{* *}\left(\varphi_{p_{2}}^{* *}\right)$,

7. Calculating the value of the acceptance constant $k$ from the formula:

$$
k=X_{\alpha}^{* *}-\varphi_{p_{2}}^{* *}
$$

8. Appointing a minimum average value of sample, which allows to accept the lot:

$$
\overline{x_{\min }}=L-k \cdot s
$$

\section{A comparative analysis of the costs of acceptance control}

In order to compare the proposed acceptance method with the classical method in terms of the generated costs, computer simulations were carried out. The starting point of the simulation process are data generated from the assumed probability distribution, reflecting a batch of products presented for inspection. These data were generated from a generalized distribution parameter lambda $\lambda_{1}=225, \quad \lambda_{2}=5, \quad \lambda_{3}=\{-0,7 ;-0,5 ; 0 ; 0,5 ; 0,7\}, \quad \lambda_{4}=\{0,01 ; 0,3 ; 0,5 ; 0,8\}$. It was assumed that the batch has 100 elements, and that acceptance control takes place in accordance with the variable evaluation of features based on 5 - element sample. It is recognized the item of product to be defective when the value of the controlled characteristics is below the lower specification limit $L=220$. It is expected that the acceptance plan guaranteed to batch of defectiveness $p_{2}=0,1$ was accepted with the probability $1-\alpha=0,95$. It is assumed, that the single cost of element control is equal $1[\mathrm{u}]$, cost of internal lack is $10[\mathrm{u}]$, and the cost of external lack reaches $30[\mathrm{u}]$.

Simulation procedure was carried out in 5 steps.

1. Generation a lot of set size from a given distribution,

2. Determination of the acceptance constant $k$ and a minimum average value of $n$-element sample, which allows to accept the lot, in accordance with the proposed algorithm and in accordance with the classical procedure,

3. Selection of the sample form batch and control selected elements,

a. The lot is accepted if the mean of the randomly taken sample is greater than or equal to the designated average minimum $\left(\bar{x} \geq \overline{x_{\min }}\right)$,

4. Calculation of the value of each acceptance control costs,

5. 1000 - times repetition of steps 1 to 4 , and averaging the results.

The results of the simulation analyses are presented in Table 1. 

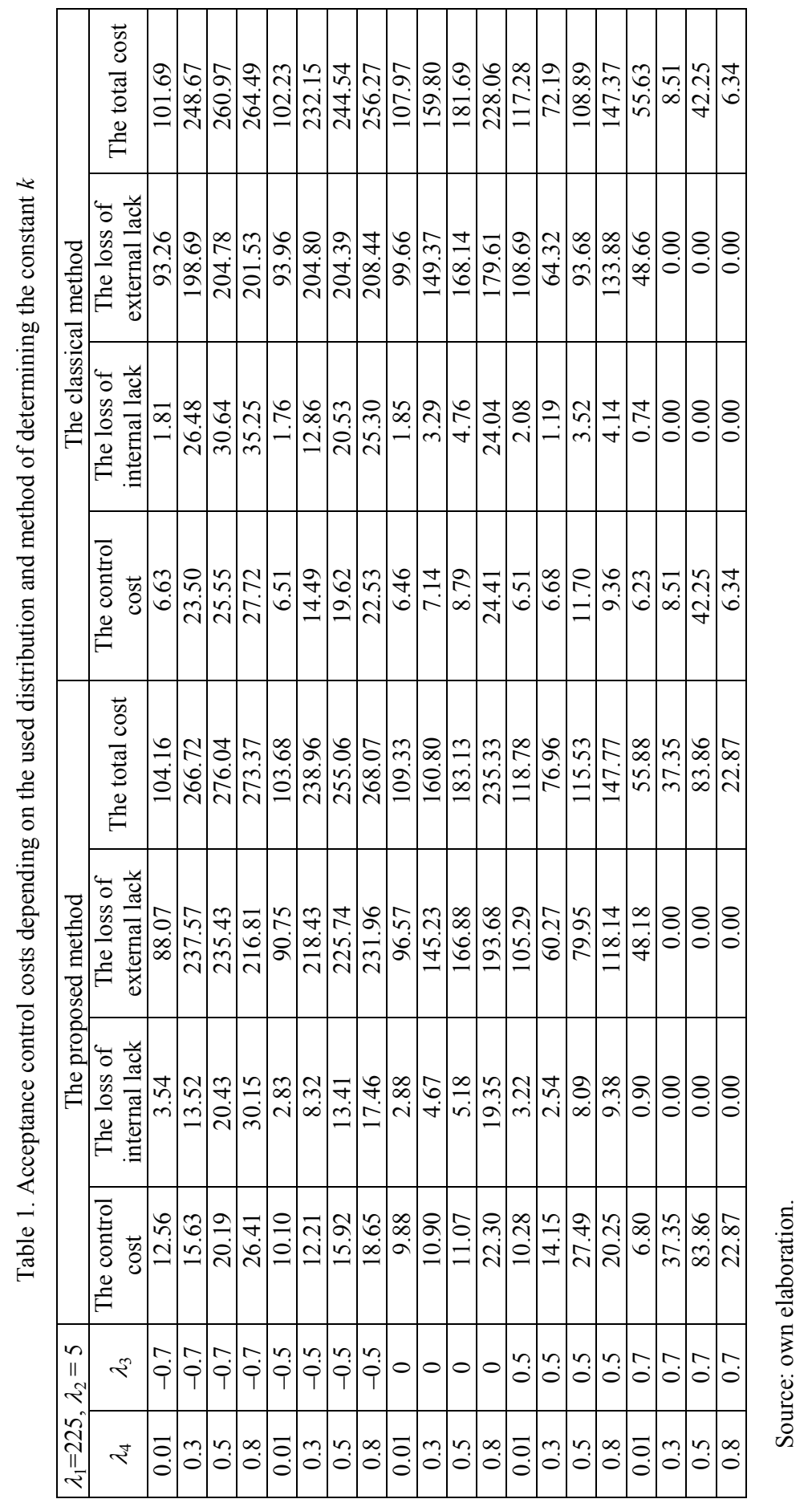
Analyzing the data in Table 1 we can see that the total cost associated with the use of the proposed method is, in any of the analyzed cases, slightly higher than the cost associated with the use of classical methods. It should also be noted that differences occur in the cost structure for the compared methods of acceptance sampling. In the case of negative asymmetry, the proposed alternative method generates lower control cost and lower cost of internal lacks and higher cost of external lacks than the classical method. In the case of a positive asymmetry these relationships are reversed. In the case of symmetry the results are at a similar level. Those dependences result directly from the inclusion in the algorithm of determining the acceptance constant $k$, distribution of the controlled characteristic, which not always follows the normal distribution (or at least symmetrical distribution). The value of the acceptance constant $k$ affects the value of the minimum average of $n$ - elemental sample, which allows to accept the lot. In the case of negative asymmetry, this average is lower for the proposed method than for the classical method, while in the case of positive asymmetry - it is higher. Moving the minimum average which allows to accept the batch of products for an alternative method of determining the constant $k$, in relation to the classical method, due to the need of ensuring by acceptance sampling plan assumed probability of taking the lot $1-\alpha$ with a given defectiveness $p_{2}$. In the classical method in the case of distribution significantly different from normal distribution this cannot be not guaranteed.

\section{SUMMARY}

An acceptance sampling is a quality assessment procedure which may be conducted on the basis of an alternative assessment, as well as on the basis of a variable assessment. Variable acceptance sampling plans require compatibility distribution of controlled characteristics with a normal distribution. The classical method in the case of characteristic having not normal distribution is incorrect method, which should not be used in such a case.

In this paper the algorithm for determining the acceptance constant $k$ of variable sampling with specified sample size and the producer's risk is presented. This method is not limited by the form of distribution of controlled characteristics. It can be used for both, when controlled characteristic follows the normal distribution, and when it does not follow its.

The carried out simulation comparative analysis of the costs of an acceptance control, at a given cost weight system, leads to a rejection of the stood hypothesis of a lower total cost generated by the plan determined in accordance with the proposed alternative approach. The disparity in the values of the total acceptance control cost and its individual components in the two 
compared methods results from the fact that the proposed method fulfills the imposed condition on the producer's risk, and the classical method for the analyzed distribution of controlled the characteristics does not satisfy this condition Moreover, it should be mentioned that by the different weighting system of unit acceptance control cost, the total cost of acceptance control in accordance with an alternative approach must not be higher than the total cost of conducting inspections in accordance with the classical approach.

\section{Acknowledgements}

The research was supported by Polish National Science Centre grant DEC-2011/03/B/HS4/05630

\section{REFERENCES}

Iwasiewicz A. (1999) Zarządzanie jakościa. PWN. Warszawa - Kraków.

Kończak G. (2007) Metody statystyczne w sterowaniu jakościa produkcji. Wydawnictwo Akademii Ekonomicznej w Katowicach. Katowice.

Montgomery D. C. (2009). Introduction to Statistical Quality Control. John Wiley\&Sons. Inc. Six Edition. New York.

Wetherill G. B.. Chiu W. K. (1975). A Review of Acceptance Sampling Schemes with Emphasis on the Economic Aspect. International Statistical Review. Vol. 43. p.191-210.

\section{Magdalena Chmielińska}

\section{KOSZTY KONTROLI ODBIORCZEJ DLA LICZBOWEJ OCENY WLAŚCIWOŚCI PRZY NIEZGODNOŚCI ROZKLADU CHARAKTERYSTYKI Z ZALOŻENIAMI}

Streszczenie. Plan odbiorczy jest procedurą rozstrzygania na podstawie próby losowo pobranej z większej partii o jakości w tej badanej partii. Kontrola odbiorcza prowadzona może być zarówno w oparciu o ocenę alternatywną, jak i w oparciu o ocenę właściwości liczbowych. Plan kontroli odbiorczej oparty na ocenie właściwości liczbowych zakłada, iż kontrolowana charakterystyka ma rozkład normalny. W artykule zostanie zaprezentowana procedura wyznaczania stałej $k$ liczbowego planu odbiorczego o zadanej liczebności próbki i ryzyku producenta, w przypadku rozkładu kontrolowanej charakterystyki istotnie różnego od rozkładu normalnego. W artykule porównano proponowaną metodę $\mathrm{z}$ metodą klasyczną pod względem generowanych kosztów. Założono, iż w przypadku rozkładów istotnie różnych od rozkładu normalnego. proponowana metoda okaże się tańsza w stosowaniu.

Słowa kluczowe: statystyczna kontrola jakości, kontrola według oceny liczbowej, koszty kontroli odbiorczej. 